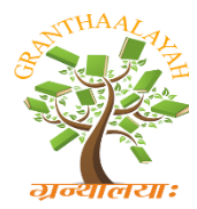

\author{
INTERNATIONAL JOURNAL OF RESEARCH - \\ GRANTHAALAYAH \\ A knowledge Repository
}

Social

\title{
BPOM JAMBI MONITORING SYSTEM AGAINST CIRCULATION OF FOOD PRODUCTS WITHOUT CIRCULAR PERMITS IN JAMBI CITY REVIEW ACCORDING TO ISLAMIC LAW
}

\author{
Siti Marlina *1 \\ ${ }^{1}$ Lecturer at the State Islamic University Sulthan Thaha Syaifuddin Jambi - Indonesia ${ }^{1}$
}

\begin{abstract}
Crime is a phenomenon of human life and society, therefore it cannot be released from space and time. The rise and fall of crime rates depends on the circumstances of the community, political conditions, economy, culture and so forth. Based on the results of research at the Jambi BPOM, the problem of crime and violations is a phenomenon that cannot be implemented in people's lives. However, not all people obey the regulations made by the government, many cases of violation of food products without marketing licenses have been successfully disclosed, for information, in 2013 to 2015, a number of 19 cases of drug circulation, cosmetics, traditional medicine and health supplements, food, which does not meet security, benefits, and quality requirements with a nominal value of Rp. 423,769,000 including: 10 cases in the field of medicine, 2 cases in the field, 5 cases in the field of cosmetics and 2 cases in the field of food. successfully revealed and has been submitted to court.
\end{abstract}

Keywords: Monitoring System; Circulation of Food Products.

Cite This Article: Siti Marlina. (2019). "BPOM JAMBI MONITORING SYSTEM AGAINST CIRCULATION OF FOOD PRODUCTS WITHOUT CIRCULAR PERMITS IN JAMBI CITY REVIEW ACCORDING TO ISLAMIC LAW." International Journal of Research - Granthaalayah, 7(7), 343-350. https://doi.org/10.29121/granthaalayah.v7.i7.2019.776.

\section{Introduction}

\subsection{Background}

Indonesia is a country based on law, not based on mere power. Law enforcement must be in accordance with the applicable provisions also based on Pancasila and the fifth precepts and at the opening of the 1945 Constitution of the Republic of Indonesia in the fourth century. (SoekarnoHatta, 1986, 57)

\footnotetext{
${ }^{1}$ Partners write and research Dr. Sumarto Lecturer at the State Islamic Institute Curup - Indonesia
} 
Based on UU No. 7 of 1996 is defined as everything derived from biological and water sources, both processed and unprocessed, which are intended as food or drink for human consumption, including food additives, food raw materials and other materials used in the preparation process, processing, and or making food or drinks. Based on Government Regulation No. 28 of 2004 concerning Food Safety, Quality and Nutrition. (Dewi Cakrawati Mustika, 2012,1-2)

FAO and WHO in 2003 introduced 3 (three) national food safety monitoring systems, namely: Single agency system - a system of supervision by one of the agencies responsible overall for protecting the community and food security and that responsibility is in the hands of the government.

Multiple agency system - a food supervision system with a multisectoral approach involving many institutions.

Integrated system - an integrated food supervision system that involves many institutions, collaborates and coordinates synergistically along the food chain in a sustainable manner. (BPOM RI, 2009, 8)

The government is responsible for regulating and overseeing outstanding food security. And food regulations without marketing authorization are regulated in article 142 which reads: "Food entrepreneurs who intentionally do not have marketing licenses for any Processed Food made domestically or imported for trading in retail packaging as referred to in Article 91 paragraph (1) shall be punished with imprisonment of a maximum of 2 (two) years or a fine maximum of Rp.4,000,000,000.00 (four billion rupiahs) ". (Laws of the Republic of Indonesia No. 18 of 2012 About Food Chapter IX of the Criminal Code).

Based on the results of the Balai POM supervision in Jambi, there were 1058 items of hard drugs (without expertise and authority), 866 items of traditional medicine without marketing authorization, 354 items of Cosmetics without marketing authorization and 11 items of distribution without distribution permit. The destruction of medicinal products and ready-made food was 2,289 items with an estimated nominal value of Rp. 650,897,500 by being crushed using heavy equipment and burning in the yard of the Office of the Drug and Food Supervisory Office in Jambi by the Head of the POM Office in Jambi.

Based on the description above, the researcher is interested in conducting research with the title. "Jambi BPOM Monitoring System Against Circulation of Food Products Without Circular Permits in Jambi City Is Observed According to Islamic Law."

\section{Theoretical Basis}

\subsection{Law Enforcement}

Law enforcement is a problem faced by the community. Law enforcement words have the connotation of enforcing, implementing provisions in the community, so that in a broader context law enforcement is a process of the realization of abstract concepts into reality. The process of law enforcement in fact peaked in its implementation by law enforcement officials themselves. 
According to Simon in his book arguing that the view of law enforcement has two views, namely a monistic view that formulates the strafbaar feait as "eene strafbaar gestelde, on the metaphor of schuld in verbal and standard handeling van een torekening vatbaar persoon" (an act threatened by punishment, contrary to law, carried out by someone who is guilty and the person is held responsible for his actions). According to the flow of monism, the strafbaar feit elements include both the element of action, which is commonly called the objective element, therefore, mixed elements of action and elements of the maker it can be concluded that starfbaar feit is the same as the terms of criminal imposition, so as if it is considered that if there is a starfbaar feit, then surely the perpetrator can be convicted. (Muladi and Dwidja Priytno, 2010,61).

Meanwhile, according to Soerjono soekanto explained that law enforcement as a process, in essence is the application of discretion which involves making decisions that are not strictly regulated by the rule of law, but have an element of personal judgment. Therefore, real consideration can only be applied to selective and crime prevention problems. Besides that, in the discretion process it must harmonize the application of the law consistently with human factors.

In the law enforcement process, there are factors that influence it. These factors are quite meaningful so that the positive and negative effects lie in the contents of these factors. According to Soerjono Soekanto that these factors are five, namely:

1) The law itself, which in this paper will be limited to the law only,

2) Law enforcers, namely those who form or implement laws,

3) Facilities or facilities that support law enforcement,

4) Society, namely the environment in which the law applies or is applied,

5) Culture, that is the work, creativity, and taste based on human intention in life. (H. Ishaq, 2006, 279-299)

Law enforcement is the duty and responsibility of the community, and judicial institutions consisting of police, prosecutors, courts and existing advocacy institutions. The realization of fair law enforcement and guaranteeing legal certainty are all citizens who have a sense of justice and have long been expect these institutions / institutions to play an active role by upholding a sense of community justice (Sutan Remy Sjahdeini, 2006, 133).

Efforts to deal with crime with criminal law in essence are also part of law enforcement efforts (especially the enforcement of criminal law). Therefore, it is often said that politics or criminal law policies are also part of law enforcement policies. (Barda Nawawi Arief, 2008, 28)

\subsection{Actors in Law}

The perpetrator is doing, especially doing something criminal by someone who is responsible intentionally or not. In connection with the perpetrator, the sentence imposed is a worthy reply or it is hoped that the perpetrator can pay for the sins of the atrocities committed to the victim. Perpetrators are subjected to severe penalties that can make him become bitter or so that in the future he will not repeat his evil deeds (J.C.T. Simorangkir, 1995, 130).

In order to know or define who the perpetrator is not difficult but not too easy. Many opinions about what the perpetrators call. One problem that often arises in people's lives is about crime and 
violation. Crime problems are an eternal problem in human life and until now the problem of crime and violations is a phenomenon that cannot be eliminated or eliminated because crime can be done in groups or individually. Crime is a phenomenon of human life and society, therefore it cannot be released from space and time. The rise and fall of crime rates depends on the circumstances of the community, political conditions, economy, culture and so forth. (Martiman Prodjohamidjojo, 1997, 2).

According to Van Hamelmem, he gives an understanding of the perpetrators of crime by making a definition that says: the perpetrator of a crime is only him, whose actions or omissions fulfill all elements of the offense as contained in the formulation of the offense concerned, whether expressly or not expressly stated. In article 55 of the criminal law (KUHP), the offender also includes those who provide wages, agreements, misuse of power, or dignity, use coercion and intentionally incite to do.

So it can be concluded that the perpetrators are not only those who commit criminal acts themselves and their actions fulfill the formulation of delicts in the law but also those who instruct them to do things, and those who with persuasion, agreements and so on make criminal acts.

\subsection{Food Products}

Food is everything that comes from biological sources of agricultural, plantation, forestry, fisheries, animal husbandry, water, and water products, both processed and unprocessed which are designated as food or beverages for human consumption, including food additives, and raw materials food and other ingredients used in the process of preparing, processing and / or making food or drinks. (Article 1 number (1) Food Law, Number 18 of 2012).

Processed Food or Food Products are foods or beverages produced by certain methods or methods with or without tambah ingredients. The term food or food in the mandarin word is written two parts one means human or human and the other means good or good. it means that food should be good, good quality and safe if consumed by humans. The term food is more used as a technical term, such as food technology, not food technology, food production rather than food production, food additives are not food additives. the term food is used for processed food. Food is a basic human need which is also a commodity of trade, requires the support of an ethical, honest and responsible food trading system so that it is affordable by the community. Food in the form of food and beverages is one of the basic human needs needed for life, growth, breeding, and reproduction.

\section{Previous Research}

Previous research is a description of the results of previous studies (other studies) related to this study on the aspects of focus / themes studied. The author finds several studies that have to do with the problems to be examined, such as the following title: "Law Enforcement of violating the code of ethics" written by Hotdo Nauli, a student at the Faculty of Law, University of Lampung, in this study focused more on efforts to overcome food additives that exceeded the maximum threshold set and / or materials that are prohibited from being used as additional ingredients. food. (Hotdo Nauli, 2017). 
Anzar La Ifu's research in the University of Halu Oleo food science and technology entitled "Law Enforcement Analysis of the synthesis of rhodamine B coloring agent on bottle chili which is traded in the modern market in the city of Kendari". in this study only discusses about identifying dyes in chilli which are sold in the modern market in the city of Kendari especially in the Hypemart and Mall Mandoga. (Anzar La Ifu, 2015).

Then in the research compiled by Restu Tjiptaningdyah, Faculty of Agriculture, University. Soetomo entitled "Analysis of Rhodamin B coloring agent on snacks which are supplied in the school environment". In this study, it was concluded that of the 20 kinds of snacks that were marketed in the school environment 30 percent or as many as 6 (six) types were identified to contain Rhodamin B synthesis dyes in snacks which were marketed in the school environment of SDN Sidokare Village, Sidoarjo District. (Restu Tjiptaningdyah, 2016).

From the three studies above, it is clearly different from the researchers who examined the research here, namely the Jambi BPOM Monitoring System Against Circulation of Food Products without Circular Licensing in Jambi City According to Islamic Law "because here the researchers examined food products that were ready to be distributed not through food permit procedures from BPOM Jambi City.

\section{Research Methodology}

The research approach used in this study is a Sociological research approach Normati fempiris focuses on behavior (behavior) that develops in society, or the operation of law in society. So the law is conceptualized as real behavior (actual behavior) which includes actions and consequences in the relationship of community life.

In empirical legal research the data needed is primary data and secondary data. Primary data, namely data obtained from the source directly from the field, such as: the location of the study, namely the environment in which the research was conducted, namely the environment in which the research was conducted. Thus primary data is often also called field data.

1) Field Research locations are writers who come to the field to conduct research on objects related to the issues discussed, in this study the data was taken from newspapers and media about the circulation of food products without marketing authorization in Jambi City.

2) Library Research is a series of activities related to library data collection methods, reading and recording and processing research materials, by examining library books as reference material related to investment problems. Field Research is the main data source in this study, and therefore library research data sources are used as supporting sources in this study.

\section{Results of Research and Discussion}

Technological advances have brought rapid and significant changes to the pharmaceutical industry, native Indonesian medicine, food, cosmetics and medical devices. By using modern technology, these industries are now able to produce on a very large scale including a variety of products with a very wide "range". With the support of the progress of transportation technology 
and the increasingly thin entry barrier in international trade, the products in a very short time can spread to various countries with a very wide distribution network and able to reach all levels of society.

Community consumption of these products tends to continue to increase, along with changes in people's lifestyles including their consumption patterns. Meanwhile, public knowledge is still inadequate to be able to choose and use products appropriately, correctly and safely. On the other hand, advertisements and promotions vigorously encourage consumers to consume excessively and often irrationally. Changes in production technology, international trade systems and consumer lifestyles in reality increase risk with broad implications for consumer health and safety. If a sub-standard product occurs, is damaged or contaminated by hazardous materials, the risks that occur will be large and wide-scale and take place very quickly.

For this reason, Indonesia must have an effective and efficient Drug and Food Monitoring System (SisPOM) that is able to detect, prevent and supervise products intended to protect the safety, security and health of its consumers both at home and abroad. For this reason BPOM has a national and international network and law enforcement authority and has high professional credibility. Throughout 2018, the Central Bureau of Drug and Food Control (BPOM) recorded 30 cases of findings, with total losses reaching Rp. 900 million to Rp. 1 billion. The value of the loss increased dramatically compared to the previous year's findings which only reached around Rp345 million. Head of Jambi Province BPOM, Antoni Asdi said, from a number of findings in the field, there were several categories ranging from medicine, cosmetics, food and traditional medicine. "The number of items from this finding is very large," Antoni said. The number of findings of the most items that do not have an official permit from BPOM during 2018 is 466 items of cosmetics, followed by 107 traditional medicines and 10 items for food. Whereas, for drugs listed $\mathrm{G}$ or those sold illegally BPOM found as many as 832 items. According to Antoni, while combing various places in the field, his team still gets a number of pharmacies that sell G-list drugs. However, they do not have permission to sell them. Besides that, there is also a cosmetic seller, where the sellers do not have official permission from BPOM. He mentioned that of the 30 more cases found in the field during 2018, there were 10 cases that had entered legal channels and five of them had already been inkracht.

"Most of the findings in the field in the city of Jambi, Tebo, Muaro Bungo and Sarolangun. In other places there is a possibility but there are not too many," he explained. To improve performance in the field, BPOM continues to improve coordination with the relevant sector level such as the Police team, National Narcotics Agency, and other related OPDs to provide a redundant effect on the perpetrators who are still selling their products outside the stipulated conditions.

Based on Article 2 of the Presidential Regulation Number 80 of 2017 concerning the Drug and Food Control Agency: BPOM has the task of carrying out government duties in the field of drug and food supervision in accordance with the provisions of the legislation. Medicines and Food as intended in paragraph (1) consist of drugs, medicinal ingredients, narcotics, psychotropic substances, precursors, addictive substances, traditional medicines, health supplements, cosmetics, and processed foods. 
Based on Article 3 of Presidential Regulation Number 80 of 2017 concerning the Drug and Food Supervisory Agency, BPOM has the function: In carrying out the task of supervising Medicines and Food, BPOM organizes functions:

1) Drafting national policies in the field of supervision of drugs and food;

2) Implementation of national policies in the field of drug and food supervision;

3) Preparation and stipulation of norms, standards, procedures and criteria in the field of supervision before circulation and supervision during circulation;

4) Implementation of supervision before circulation and supervision during circulation;

5) Coordination of the implementation of drug and food supervision with central and regional government agencies;

6) Providing technical guidance and supervision in the field of supervision of drugs and food;

7) Implementation of repression against violations of the provisions of laws and regulations in the field of drug and food supervision;

8) Coordination of task implementation, guidance, and administration of administrative support to all organizational elements within the bpom;

9) Management of state property / assets which are the responsibility of bpom;

10) Supervision of the implementation of duties within the bpom; and

11) Implementation of substantive support to all organizational elements within the bpom.

Pre-Circular Supervision as referred to in paragraph (1) is the supervision of drugs and food before circulating as a preventive measure to ensure that circulating drugs and food meet the standards and requirements for safety, efficacy / benefits, and the quality of the products specified.

Supervision During Circulation as referred to in paragraph (1) is the supervision of drugs and food as long as they are circulated to ensure that circulating drugs and food meet the standards and requirements for safety, efficacy / benefits, and determined product quality and law enforcement measures. Based on Article 4 of the Presidential Regulation Number 80 of 2017 concerning the Food and Drug Supervisory Agency In carrying out the task of supervising Medicines and Food, BPOM has the authority: issue marketing authorization of products and certificates in accordance with the standards and requirements of security, efficacy / benefits and quality, and testing of drugs and food in accordance with the provisions of legislation; conduct intelligence and investigation in the field of supervision of drugs and food in accordance with the provisions of the legislation; and granting administrative sanctions in accordance with the provisions of the legislation.

Process of product permission to BPOM Jambi:

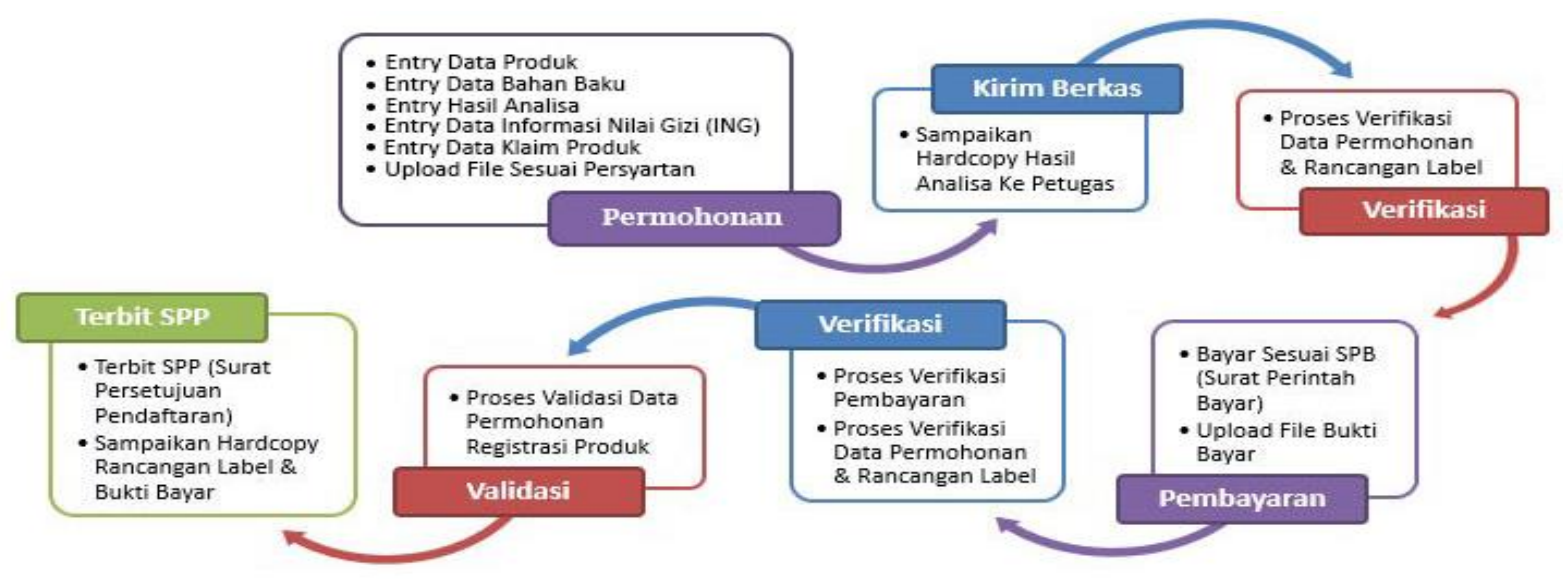




\section{References}

[1] Soekarno Hatta, Sejarah Lahirnya Undang-Undang Dasar 1945 dan Pancasila, Jakarta : Inti Idaya Press, 1986

[2] Martiman prodjohamidjojo, Memahami Dasar-Dasar Pidana Indonesia, cet, ke-2 : Jakarta Pradya Pramatis, 1997

[3] Dewi Cakrawati Mustika, bahan pangan, gizi, dan kesehatanBandung: Alfabeta, 2012Cetakan Kesatu: September 2012

[4] BADAN POM RI, direktori keamanan pangan indonesia, badan pengawas obat dan makanan republik indonesia Jakarta: Direktorat SPKP, Deputi III, Badan POM RI, 2009, Cet 2,

[5] Tjahja Muhandri, Sistem Jaminan Mutu Industri Pangan, Bogor: IPBPERS, 2006

[6] Undang - UndangRepublik Indonesia No. 18 Tahun 2012 Tentang Pangan

[7] Muladi dan dwidja priytno, Pertanggung Jawaban Pidana KorupsiJakarta : kencana, 2010

[8] H. Ishaq, Dasar-Dasar Ilmu HukumJakarta: Sinar Grafika, 2006 Cet-1,

[9] Sutan Remy Sjahdeini, Kapita Selekta Penegakan Hukum di Indonesia, Jakarta: Prestasi Pustaka, Cetakan Pertama Mei 2006

[10] Barda Nawawi Arief, kebijakan hukum pidana, perkembangan konsep KUHP baruJakarta: KENCANA prenadamedia group, 2008

[11] Abdul R. Saliman, Hukum Bisnis Untuk Perusahaan teori dan contoh kasus,Jakarta: Kencana Prenadamedia Group, 2005 Edisi Keempat

[12] J.C.T. SimorangkirDkk, KamusHukum, Jakarta: BumiAksara, 1995

[13] http://putranto88.blogspot.com/2011/06/pelaku.html di aksespadatanggal 29 september 2017 pukul 09.45 A.M

[14] Pasal 1 angka (1) Undang-Undang Pangan, Nomor 18 Tahun 2012

[15] http://biotekn.blogspot.co.id/2013/04/definisi-pangan.html di akses kamis 21Desember 2017, 15:23 WIB

[16] Hotdo Nauli, Upaya penanggulangan terhadap peredaran jajanan anak sekolah yang mengandung bahan berbahaya oleh BPOM Lampung Skrpsi Fakultas Hukum Universitas Lampung, 2017

[17] Anzar La Ifu, Analisis kandungan zat pewarna sintesis rhodamin B pada sambal botol yang di perdagankan di pasar modern kota kendari Skripsi Fakultas Teknologi dan Idustri Pertanian Universitas Halu Oleo, 2016

[18] Restu Tjiptaningdyah, Analisis zat pewarna rhodamin B pada jajanan yang dipasrkan di lingkungan sekolah,Studi kasus Sekolah SDN Kelurahan Sidokare Kecamatan Sidoarjo Skripsi Fakultas pertanian Universitas Dr. Soetomo, 2016

[19] H. Ishaq, Metode Penelitian Hukum Dan Penelitian Skripsi, Tesis, Serta Desertasi, Kerinci: STAIN Krinci press, Edisi Revisi 2015, Cet ke-4,

[20] Imam Gunawan, metode penelitian kualitatif teori \& praktik, Cet. ke-3 Jakarta: Bumi Aksara, 2015

[21] H. Ishaq, Metode Penelitian Hukum Dan Penelitian Skripsi, Tesis, Serta Desertasi, Kerinci: STAIN Krinci press, Edisi Revisi 2015, Cet ke-4

[22] Sugiyono, Metode penelitian Kuantitatif Kualitatif dan RND, Bandung: Alfabeta, 2013 